\title{
ORGANIZING PROFESSIONAL TRAINING OF STUDENTS BY SOLVING PROBLEMS OF ECONOMIC CONTENT IN TEACHING MATHEMATICS
}

\author{
Nurseyit Alijan Oglu Beketov
}

Teacher, Methods Of Primary Education Department, Chirchik State Pedagogical Institute, Tashkent Region, Uzbekistan

\section{ABSTRACT}

In this article, the use of practical issues in economic interpretation in the teaching of mathematics in today's system of continuing education is a key step in the development of professional training of students. It is also important to improve the quality of continuing education, to teach students to think independently in mathematics, to strengthen their socio-economic, scientific and technical knowledge of mathematics. In addition, the emphasis on the use of economic issues in the formation of scientific and theoretical thinking in the teaching of mathematics will further expand the opportunities for students to acquire knowledge, professional training, and become competitive in the future.

KEYWORDS:- Teaching methods, mathematics teaching methods, lifelong learning, modeling, induction, deduction, innovative technologies.

\section{INTRODUCTION}

Continuing education is the basis of the system of training, ensuring the socio-economic development of the Republic of Uzbekistan, a priority area that meets the economic, social, scientific, technical and cultural needs of the state. Therefore, in the process of education today, the main task of every science teacher is not only to teach students, but also to apply them in practice, to teach them to think independently, to develop their abilities, and to educate them based on national and universal values.

Advanced teaching experience shows that inclass and extracurricular activities are designed to equip students with economic knowledge so that they can actively participate in market relations, as well as to teach them the science of "ownership and entrepreneurship." New forms and methods of developing economic culture in students are being used to explain economic knowledge, information about the life and economy of our country.

\section{AnAlysis AND METhodologY}

In covering issues of practical content, it is expedient to conditionally categorize existing economic issues and problems. In this context, we can conditionally divide economic issues and problems into the following types: 
CURRENT RESEARCH JOURNAL OF PEDAGOGICS 2(9): 130-135,

September 2021 DOI: https://doi.org/10.37547/pedagogics-crjp-02-09-29

ISSN 2767-3278

(C)2021 Master Journals

\section{Crossref do) 8 Google}

Accepted 25 $5^{\text {th }}$ September, 2021 \& Published $30^{\text {th }}$ September, 2021

economic issues encountered in the personal and family life of people;

economic issues and problems in the private sector;

issues and problems that exist and need to be addressed at the national level;

Current and potential issues and problems in interstate relations;

universal, that is, the problems that humanity may face today and in the future;

Problems related to various areas of existing objective and subjective significance.

When a certain amount of money is lent, it is agreed that the borrower will repay the amount (debt) to the lender (creditor) within the given period.

In addition, each borrower undertakes to pay an additional fee to the lender.

Obviously, the amount paid by the debtor depends on the amount of the loan, the repayment period and the interest rate set by the lender for the purpose of earning income.

Two methods are usually used to calculate the income that a creditor receives as a result of lending a certain amount of money to a debtor within a specified period: simple (simple) interest and complex interest methods.

Simple interest is a method of calculating the income that a creditor receives as a result of lending a certain amount of money to a debtor for a specified period.

Simple interest calculation formula:

$$
I=\frac{C r n}{100}
$$

Complex interest calculation formula:

$$
A=C\left(1+\frac{r}{100}\right)^{n}
$$

Here, $\mathrm{C}$ is the amount of the original loan, and I is the amount of interest that the debtor pays to the creditor for using the amount of money. This parameter is also called interest or, more simply, interest, $r$ is the annual interest rate, and $n$ is the number of years.

\section{Results}

Economic issues and problems in the personal life of each person include issues related to his economic position in society, daily, monthly, annual income and expenses, his personal economic plans, the economic benefits he brings to himself and members of society. can be added.

Let's look at the following issue.

Masala. If the average salary of a regular school teacher is 1.3 million soums, and the income from various extracurricular activities is 200,000 soums per month:

1) create a diagram of the teacher's daily, monthly, quarterly and annual income;

2) If his average daily expenses are 15,000 soums, determine the daily, monthly, quarterly and annual real income that the teacher brings to his family and make a diagram.

Solution. We calculate the total monthly income of a teacher

$1300000+200000=1500000$ sum.

Assuming an average of 30 days a month, we find its daily income

$1500000 \div 30=50000$ sum

In that case its quarterly and annual revenues

It will be, $1500000 \times 3=4500000$ sum and $1500000 \times 12=18000000$

We will create a diagram of the teacher's daily, monthly, quarterly and annual income.

If the teacher's daily expenses are 15,000 soums, 
CURRENT RESEARCH JOURNAL OF PEDAGOGICS 2(9): 130-135,

September 2021 DOI: https://doi.org/10.37547/pedagogics-crjp-02-09-29

ISSN 2767-3278

(C)2021 Master Journals

\section{Crossref do: 81 Google}

Accepted 25th September, 2021 \& Published 30 ${ }^{\text {th }}$ September, 2021

his real daily income is $50,000-15,000=35,000$ soums, then:

The real monthly income of a teacher is $35000 \times 30=1050000$ soums,

real income for the quarter $1050000 \times 3=$ 3150000 soums,

annual real income is $1050000 \times 12=$ 12600000 soums.

Based on these results, we create a diagram of the real income of the teacher and compare the two diagrams.

Now, we come to the part where we talk about the middle ground.

It is known that today in our country private and small business is developing rapidly, its role in our society is growing rapidly. Therefore, solving issues and problems in this sector is very important for each of us. Creating business plans in this area, that is, working on the basis of accurate calculations in business development, will determine the future of any planned business. Let's look at the following issue.

Masala. The farmer received a state order. According to him, the farmer must develop rabbit breeding and supply at least 1,200,000 rabbits to the state after 3 years. (1 rabbit multiplies 2 times a year and an average of 4 during each incubation period). How to start a business to fulfill an order?

Solution. It is advisable to conduct such problems in classes with exponential and logarithmic functions.

The reproductive function of 1 rabbit is $u=4^{\wedge} \mathrm{x}$, where $\mathrm{x}$ is the incubation period. 2 incubation periods are 1 year. This means that the farmer has to fulfill the order in 3 years, ie in 6 incubation periods. 1 rabbit can multiply in 3 years $u=4^{\wedge} 6=4096$ rabbits, but this does not fulfill the order. So we add a parameter to the multiplication function

$$
\begin{gathered}
u=a \times 4^{x}=a \times 4^{6}=4096 \\
a>1200000 \text { or } a>1200000 \div \\
4096=293 .
\end{gathered}
$$

This means that the farmer will have to start raising at least 293 rabbits. Answer: A farmer should start by raising at least 293 rabbits.

Now, we come to the part where we talk about the middle ground, which is to teach math. The solution to such problems differs from the above in its multi-stage nature.

Masala. The government has set a task to raise 30 million rabbits in the country over 3 years, involving 15 farms. Create a business project.

Solution. In such cases, it is advisable to use the principle of even distribution of the task, ie to set the task for each farmer to raise $30000000 \div 15$ $=2000000$ rabbits. This is also convenient in terms of managing farmers 'activities and processes. Now we can use the private sector approach.

$$
\text { Then } u=a \times 4^{x}=a \times 4^{6}>
$$

\section{0}

\section{$4096 a>2000000$ or $a>488$}

This means that every farmer should start by raising at least 488 rabbits. In the republic it is necessary to start with $488 \times 15=7320$ rabbits. In order to solve such problems, it is advisable to divide the students into small groups and use design methods.

Masala. If 8,000,000 soums are received at the rate of $7 \%$ per annum for 18 months, calculate the interest payment.

Solution. Since this problem is a simple percentage, we calculate using formula (1): 


$$
C=8000000, \quad r=7 \%, \quad n=\frac{18}{12}=1.5 \text { year }
$$

So,$I=\frac{C r n}{100}=I=\frac{8000000 \cdot 7 \cdot 1.5}{100}=840000$ soum.

Answer: 840000 soum.

Masala. He initially lent $\$ 2,000$ to the lender and received a total of $\$ 3,000$ after several years of annual repayment. If the interest rate is set at $12.5 \%$ per annum, how many years have the payments been made?

Solution. The lender received income in the amount of 3000-2000 $=1000$ USD.

According to the simple interest formula

$I=\frac{C r n}{100}$, bu yerda $I=1000 ; C=2000 ; r=12,5 \%$.

So, $1000=\frac{2000 \cdot 12,5 \cdot n}{100}$

Answer: 4 year.

Masala. What is the income of the lender if the loan is $\$ 10,000$ with a compound interest rate of $6 \%$ per annum?

Solution.

\begin{tabular}{|c|c|c|c|}
\hline Quarter & Loan (1) \$ & Interest payment $I=\frac{C r}{100}(2) \$$ & Balance (1) + (2) \$ \\
\hline 1 & 10000,00 & $10000,00 \times \frac{6}{100} \times \frac{1}{4}=150,00$ & 10150 \\
\hline 2 & 10150,00 & $10150,00 \times \frac{6}{100} \times \frac{1}{4}=152,25$ & 10302,25 \\
\hline 3 & 10302,25 & $10302,25 \times \frac{6}{100} \times \frac{1}{4}=154,53$ & 10456,78 \\
\hline 4 & 10456,78 & $10456,78 \times \frac{6}{100} \times \frac{1}{4}=156,85$ & 10613,63 \\
\hline
\end{tabular}

Answer: \$ 613.63 in revenue. 
CURRENT RESEARCH JOURNAL OF PEDAGOGICS 2(9): 130-135,

September 2021 DOI: https://doi.org/10.37547/pedagogics-crjp-02-09-29

ISSN 2767-3278

(C)2021 Master Journals

\section{Crossref do) 81 Google}

Accepted 25 $5^{\text {th }}$ September, 2021 \& Published 30 ${ }^{\text {th }}$ September, 2021

We now solve this problem by relying on a complex interest formula (2):

$$
\begin{aligned}
& C=10000, \quad r=6, \quad n=4 . \\
& A=C\left(1+\frac{r}{100}\right)^{n}=10000 \cdot\left(1+\frac{6}{100}\right)^{4}=10613,63 . \\
& A-C=10613,63-10000=613,3
\end{aligned}
$$

Answer: \$ 613.63 in revenue.

\section{Conclusion}

In short, today the types of economic issues, the role and importance of simple and complex interest concepts in various fields have been studied, and the development of economic sectors is very important in the life of the country. One of the most important tasks today is to increase students' interest in various sectors of the economy in mathematics, to explain the life and economy of our country, and to develop the economic skills of young people.

\section{REFERENCES}

1. Use Of Historical Materials In Teaching Mathematics In Continuous Education. GB Kuzmanova, NAO Beketov. The American Journal of Social Science and Education Innovations 2 (09), 531-537, 2020

2. Methodology of Teaching Economic Problems Based On Mathematic Modeling In Mathematics Courses. N Beketov. The American Journal of Applied Sciences 3 (04), 250-255

3. The educational significance of textual issues in general secondary schools. GB Kuzmanova. Academic research in educational sciences 2 (3), 1154-1159.
4. The importance of the innovative cluster method in the teaching of textual problems in mathematics lessons in general secondary schools. GB Kuzmanova. Economics and Society 4 (83).

5. Creation of a New Generation of Teaching Literature - A Requirement of Modernity // Абдуллаева Б.П. Мамадалиев К.Р., Жабборова O.M., Умарова 3.A. SCOPUS International Journal of Psychosocial Rehabilitation, 24 (1), 612-619 35* 2020 MAKTABGACHA TA'LIM MUASSASASIDA FUTBOL DARSLARINI TASHKIL ETISH METODIKASI B.P. Abdullayeva, B.P. Babaraximova Academic research in educational sciences 3

$$
2020
$$

6. Corruption in the field of education: assessments and ways to address “Тенденции и перспективи развития науки и образования в условиях глобализации" B.P. Abdullaeva, M. Turdalieva. Международной научнопрактической интернет-конференции. г. Переяслав, Украина 22020

7. USING INFORMATION AND COMMUNICATION TECHNOLOGIES IN TEACHING PROCESS OF VARIOUS PRIMARY SCHOOL Abdullaeva, B. Babarakhimova, B.P. Pardayev European Journal of Research and Reflection in Educational Sciences Vol 8 (10) 
CURRENT RESEARCH JOURNAL OF PEDAGOGICS 2(9): 130-135,

September 2021 DOI: https://doi.org/10.37547/pedagogics-crjp-02-09-29

ISSN 2767-3278

(C)2021 Master Journals

Crossref dof 81 Google

Accepted 25 $5^{\text {th }}$ September, 2021 \& Published 30 ${ }^{\text {th }}$ September, 2021

8. Teaching A Child To Play Football From A Youth B.P. Abdullaeva The American Journal of Interdisciplinary Innovations and Research $3(04 \ldots \quad 2021$

9. MAKTABGACHA TA'LIM TASHKILOTLARIDA FUTBOL ELEMENTLARINI O'RGATISHDA QO'LLANILADIGAN ASOSIY MEZONLAR Abdullayeva B.P. Экономика и социум 4 (4), 850-855 2021

10. МАКТАБГАЧА ТАЪЛИМ ТАШКИЛОТЛАРИ ВА БОШЛАНҒИЧ СИНФЛАРДА ЖИСМОНИЙ ТАРБИЯ МАШҒУЛОТЛАРИНИ ТАШКИЛ ҚИЛИШ Б.П. Абдуллаева Academic research in educational sciences 2 (3) 2021

11. Organization and methodology of conducting football lessons in a preschool institution B.P. Abdullaeva ACADEMICIA: AN INTERNATIONAL MULTIDISCIPLINARY RESEARCH JOURNAL 11 (1), 650-655 2021

12. Ismatullayeva, N. R. (2021). On the Introduction of E-Learning Portfolio in the Educational Process. Current Research Journal of Pedagogics (2767-3278), 2(09), 35-37. 